Archives of Business Review - Vol. 8, No.11

Publication Date: November 25, 2020

DOI: $10.14738 / a b r .811 .9340$.

Putra, R. N. P., Aysik, N. F., \& Fidiana, (2020). Financial Ratio Determinants of Capital in the Banking Sector Listed on the Indonesia

Stock Exchange (IDX). Archives of Business Research, 8(11). 165-173.

\title{
Financial Ratio Determinants of Capital in the Banking Sector Listed on the Indonesia Stock Exchange (IDX)
}

\author{
Revian Nico Pradana Putra \\ STIESIA, Surabaya \\ Nur Fadjrih Asyik \\ STIESIA, Surabaya
}

Fidiana

STIESIA, Surabaya

\begin{abstract}
This research raises the topic "Financial Determinants of Capital in the Banking Sector Listed on the Indonesia Stock Exchange (BEI)". The population in this study are conventional banking companies listed on the Indonesia Stock Exchange (BEI). The sample in this study were 26 conventional banking companies listed on the Indonesia Stock Exchange that published annual reports from 2014 to 2018. The sampling technique used in this research was purposive sampling method. Analysis of the data in this study using Multiple Linear Regression Analysis, while testing the hypothesis using the F test, R2, and $t$ test. From the results of the $F$ test, the significance value is 0.002 . The significance value is less than 0.05 . So it can be concluded that the variable Return on Assets (ROA), Operational Costs on Operational Income (BOPO), Non Performing Loans (NPL) and Loan to Deposit (LDR) have a regression equation that is a fit model. The value of $R$ Square is 0.998 or $99.8 \%$, which means that the ability of the independent variables ROA, BOPO, NPL and LDR to explain the dependent variable CAR is $\mathbf{9 9 . 8 \%}$. The correlation value (R) of 0.397 or $39.7 \%$ indicates the correlation or closeness of the relationship between the independent variables, namely ROA, BOPO, NPL and LDR to the dependent variable, namely CAR, is $39.7 \%$. In the ROA variable, it has a $t$ value of 164,987 and a significance value of 0.023 which is smaller than 0.05 , it can be concluded that ROA has an effect on CAR. The BOPO variable has a $t$ value of 0.330 and a significance value of 0.743 which is greater than 0.05 , it can be concluded that BOPO has no significant effect on CAR. In the NPL variable, it has a t value of $\mathbf{- 0 . 5 1 5}$ and a significance value of 0.608 which is greater than 0.05 , it can be concluded that NPL has no effect on CAR distribution. In the LDR variable, it has a $t$ value of 1,224 and a significance value of 0.225 greater than 0.05 , it can be concluded that the LDR has no significant effect on CAR.
\end{abstract}

Keywords: ROA, BOPO, NPL, LDR, CAR 
Putra, R. N. P., Aysik, N. F., \& Fidiana, (2020). Financial Ratio Determinants of Capital in the Banking Sector Listed on the Indonesia Stock Exchange (IDX). Archives of Business Research, 8(11). 165-173.

\section{INTRODUCTION}

Bank is an industry engaged in the field of trust, which in this case acts as a financial intermediary media between parties who have excess funds and those who need funds, namely by collecting funds from the public with excess funds and channeling them to parties who need funds, in the form of granting of credit. Considering the funds managed by the bank are funds from the public, it is very necessary to have good management in all aspects of its operations. (Financial Services Authority, 2016).

The Capital Adequacy Ratio (CAR) in the banking industry is in accordance with applicable regulations in Indonesia, the amount is determined by how much capital is owned which consists of core capital and supplementary capital, as well as how many risk-weighted assets, where the risk weight of each asset has been determined. by 0JK (Financial Services Authority). The minimum capital adequacy requirement for banks is based on the risk of bank assets listed on the balance sheet as well as administrative assets which constitute contingent commitment obligations, where the risk of these assets can be in the form of credit risk, interest fluctuations, exchange rate fluctuations, and price fluctuations of securities.

The purpose of the bank is to maintain public or customer trust in the banking industry. In carrying out bank functions, banks need sufficient capital to be able to cover losses arising from bank operations. The level of capital capacity of a bank can be measured using financial ratios, one of which is the Capital Adequacy Ratio (CAR), which is a benchmark for assessing the level of capital adequacy of a bank that is oriented towards international standards with the aim that the bank is able to absorb losses that may arise in the future.

Sudirman (2014: 93) also states that the bank's obligation to provide minimum capital is $8 \%$. To measure the fulfillment of capital obligations, it can be calculated by the Capital Adequacy Ratio (CAR). The Capital Adequacy Ratio is an indicator of a bank's ability to overcome or cover a decline in its assets as a result of bank losses caused by risky productive assets. The most profitable banks tend to have relatively high capital arrangements.

The liquidity aspect is an aspect to determine or measure the ability of a bank to meet its shortterm obligations or obligations that are due. The liquidity aspect of a bank can be measured using financial ratios, including the Loan to Deposit Ratio (LDR).

Asset quality assessment is an assessment of the condition of bank assets and the adequacy of credit risk management (Veithzal Rivai, et al, 2013: 473). To measure this ratio, several ratios can be used, including the Noan Performing Loan (NPL).

The Efficiency aspect is an important factor in assessing the performance of a bank management, especially its ability to use all of its production factors effectively and efficiently. To measure the level of efficiency and bank performance, you can use the BOPO (Operating Expenses to Operating Income) Ratio.

The profitability aspect is to measure and analyze the level of business efficiency and profitability achieved by the bank concerned. This profitability ratio plays a role in covering the Liquidity Ratio and Solvency Ratio, this is because this ratio measures the income or profit earned by the bank 
which will be used to meet its short-term and long-term obligations so that the bank's liquidity and solvency remain in good condition. Profitability ratio analysis of a bank is as follows: Return On Assets (ROA). (Andini, et al, 2015)

\section{Bank Capital}

\section{LITERATURE REVIEW AND HYPOTHESIS DEVELOPMENT}

Capital is a part of funds that can be used by banks in their daily activities. The important thing related to fund issues is how to carry out fund management activities. Fund management is the process of managing, collecting and allocating public funds as well as effectively and efficiently achieving the goals of the bank itself. (Financial Services Authority, 2016).

Capital also has several functions in banking, including: (i) To protect uninsured depositors, when the bank is insolvable and in liquidation. (ii) To absorb unexpected losses in order to maintain public confidence that the bank can continue to operate. (iii) To obtain physical advice on other basic needs funds required to offer bank services. (iv) As a means of implementing inappropriate asset expansion control regulations.

Banking capital in Indonesia is measured by CAR. Companies that have optimal capital will also produce an optimal rate of return so that not only the company gets the profit, but the shareholders also get the profit. Stating that the capital ratio commonly used to measure bank health is the Capital Adequacy Ratio (CAR). The amount of CAR is measured by the ratio of own capital to Risk Weighted Assets (RWA). In accordance with (Banking Supervision Report, 2014). The amount of CAR that must be achieved by a bank is at least $8 \%$ since the end of 2014, and since the end of 2016 the CAR that must be achieved is at least $8 \%$.

\section{Profitability}

Profitability is the company's ability to earn profits in relation to sales, total assets and own capital. The profitability of a company will affect the policies of investors on the investment made. The company's ability to generate profits will be able to attract investors to invest their funds in order to expand their business, on the other hand, a low level of profitability will cause investors to withdraw their funds. As for the company itself, profitability can be used as an evaluation of the effectiveness of the management of the business entity. Thus, long-term investors will be very interested in this profitability analysis.

ROA is one of the most important profitability ratios used to predict the price or return of shares of public companies. profitability is one of the financial ratios used for fundamental analysis. ROA is used to measure the effectiveness of the company in generating profits by utilizing the total assets owned by the company. ROA is also the multiplication of net income margin (NIM) factor and asset turnover.

ROA is used to measure the effectiveness of a company in generating profits by utilizing its assets. ROA measures the rate of return on assets that have been invested by the company. The greater the ROA of a bank, the greater the level of profit achieved by the bank and the better the position of the bank in terms of asset use. In other words, the greater the level of profit achieved by the bank and the better the position of the bank in terms of asset use". With the greater the Return on Assets 
Putra, R. N. P., Aysik, N. F., \& Fidiana, (2020). Financial Ratio Determinants of Capital in the Banking Sector Listed on the Indonesia Stock Exchange (IDX). Archives of Business Research, 8(11). 165-173.

(ROA), the Capital Adequacy Ratio (CAR) will also increase. Every time a bank makes a profit, its capital will increase".

H1: Return on Assets (ROA) has a positive effect on the Capital Adequacy Ratio (CAR)

\section{Operational Costs on Operational Income (BOPO)}

The BOPO ratio is the ratio between Operating Costs and Operating Income. The operational cost ratio is used to measure the level of efficiency and the ability of a bank to carry out its operational activities. The smaller the BOPO, the more efficient the bank is in carrying out its business activities. In a healthy bank, the BOPO ratio is less than 1 , while the unhealthy bank has a BOPO ratio of more than 1 (Fatimah, 2013).

The Efficiency aspect is an important factor in assessing the performance of a bank management, especially its ability to use all of its production factors effectively and efficiently. To measure the level of efficiency and bank performance, you can use the BOPO (Operating Expenses to Operating Income) Ratio.

If the bank is unable to maintain the efficiency of Operational Costs and is greater than the Operating Income, then this condition will cause the profit to be obtained by the bank to decrease, in other words the greater the value of BOPO reflects the lack of efficiency of the bank in carrying out its operational activities. From the explanation above, it can be concluded that with a low operating profit value, the CAR value will also be low.

H2: Operational Costs on Operating Income (BOPO) have a positive effect on the Capital Adequacy Ratio (CAR)

\section{Non Performing Loan (NPL)}

Non-Performing Loans can be seen from how many non-performing loans there are in a bank. According to (Fitrianto, 2016) Non-Performing Loans are loans that experience repayment difficulties due to deliberate factors and / or external factors beyond the control of the debtor. If a bank has a low Non-Performing Loan it means that the existing non-performing loans are getting lower, on the other hand, if the Non-Performing Loan is getting higher, the non-performing loans given by the debtor to a bank are getting higher.

The decline in non-performing loans is expected to affect the decline in non-performing loans in a banking company, but with the increase in non-performing loans, it causes an increase in nonperforming loans and results in a decrease in profit that should be received from loan interest. The decline in profit has an impact on the Capital Adequacy Ratio, because profit is one of the components that influences the formation of the capital structure of a banking company.

H3: Non Performing Loans (NPL) have a negative effect on the Capital Adequacy Ratio (CAR)

\section{Loan to Deposit Ratio (LDR)}

Used to assess the liquidity of a bank by dividing the amount of credit by the amount of funds. Loan to Deposit Ratio (LDR) is a ratio that shows the ability of a bank to provide funds to its debtors with capital owned by the bank and funds that can be collected from the public. 
If the bank can channel all the funds collected it will indeed be profitable, but this is related to the risk if at any time the owner of the funds withdraws his funds or the user of the funds cannot be exposed to risk due to the loss of opportunity to gain profit, the minimum loan limit given by the bank is $80 \%$ and $110 \%$ maximum.

The liquidity aspect is an aspect to determine or measure the ability of a bank to meet its shortterm obligations or obligations that are due. The liquidity aspect of a bank can be measured using financial ratios, including the Loan to Deposit Ratio (LDR). Measurement of bank liquidity can be done by using the credit to funds ratio received by the bank or the Loan to Deposit Ratio (LDR). Managers in a company as the recipient of the trust from the owner of the company should determine policies that can increase the importance of the Loan to Deposit Ratio (LDR) used to assess the liquidity of a bank by dividing the amount of credit by the amount of funds. Loan to Deposit Ratio (LDR) is a ratio that shows the ability of a bank to provide funds to debtors with capital owned by the bank and funds that can be collected from the people of Dendawijaya (2015). So that the lower this ratio will increase bank capital. Because if managers in the banking sector are unable to increase this ratio, it will reduce the Capital Adequacy Ratio (CAR).

\section{H4: Loan Deposit Ratio has a positive effect on Capital Adequacy Ratio (CAR)}

\section{RESEARCH METHODOLOGY}

The sampling criteria in this study were conventional banking companies listed on the Indonesia Stock Exchange (IDX) for the 2014-2018 period using purposive sampling method with a sample size of 26 . The data source used in this study was secondary data obtained through the website www.idx. co.id. In this study, the data collection technique used was documentation in which this study obtained adta from financial reports.

In this study, the data analysis method used is the Multiple Linear Regression Analysis method, because the purpose of this study is to determine the effect of independent variables on the dependent variable. Several stages were carried out in data analysis, namely: descriptive analysis, classic assumption test, normality test, multicollinearity test, autocoleration test, heteroscedasticity test, $\mathrm{F}$ test, determination coefficient test and hypothesis testing. The regression equation for this study is as follows: $\mathrm{CAR}=\mathrm{a}+\beta 1 \mathrm{ROA}+\beta 2 \mathrm{BOPO}+\beta 3 \mathrm{NPL}+\beta 4 \mathrm{LDR}+\varepsilon$

\section{Research Results}

\section{RESULTS AND DISCUSSION}

In the research results tested using SPSS for windows v.22, all research variables have passed the Classical Assumption test. The results of the normality test are Kolmgorof-Smirnov (K-S) and Asymp. The sig of all variables has a value above $\alpha=0.05$, which means that the data is normally distributed. The multicollinearity test results show that all independent variables have a tolerance value of more than 0.10 and a VIF value below 10, it can be concluded that this study does not have a multicolinearity problem. Autocoleration test results show that the DW value is greater than 1.65 and less than 2.35, so the DW value does not occur autocoleration. The results of the heteroscedasticity test state that the significance value for each independent variable on the absolute residual value is greater than 0.05 , which means that there are no symptoms of heteroscedasticity in this study. 
Putra, R. N. P., Aysik, N. F., \& Fidiana, (2020). Financial Ratio Determinants of Capital in the Banking Sector Listed on the Indonesia Stock Exchange (IDX). Archives of Business Research, 8(11). 165-173.

\section{Test the coefficient of determination}

Table 1: Determination Coefficient Test

\begin{tabular}{|c|c|c|c|}
\hline \multicolumn{4}{|c|}{ Model Summaryb } \\
\hline Model & R & R Square & Adjusted R Square \\
\hline 1 &, $397 a$ &, 998 &, 997 \\
\hline
\end{tabular}

The table above shows the R Square value of 0.998 which means that it is $99.8 \%$ which means that the ability of the independent variables ROA, BOPO, NPL and LDR in explaining the dependent variable CAR is $99.8 \%$. The correlation value (R) of 0.397 or $39.7 \%$ indicates a correlation or closeness of the relationship between the independent variable and the dependent variable.

\section{Moderate Regression Analysis}

Table 2: Regression Analysis Results

\begin{tabular}{|c|c|c|c|c|c|c|}
\hline \multicolumn{7}{|c|}{ Coefficientsa } \\
\hline & \multirow{2}{*}{ Model } & \multicolumn{2}{|c|}{ Unstandardized Coefficients } & \multirow{2}{*}{$\begin{array}{c}\begin{array}{c}\text { Standardized } \\
\text { Coefficients }\end{array} \\
\text { Beta } \\
\end{array}$} & \multirow{2}{*}{$\mathbf{t}$} & \multirow{2}{*}{ Sig. } \\
\hline & & B & Std. Error & & & \\
\hline \multirow{5}{*}{1} & (Constant) & ,025 & ,022 & & & \\
\hline & ROA & 9,677 & ,059 & ,999 & 164,987 & ,023 \\
\hline & BOPO & 2,468 & 000 & ,002 & 330 & ,743 \\
\hline & NPL &,- 004 & ,008 &,- 003 &,- 515 & 608 \\
\hline & LDR & ,003 & 002 & 007 & 1,224 & ,225 \\
\hline \multicolumn{7}{|c|}{ a. Dependent Variable: CAR } \\
\hline
\end{tabular}

$$
\mathrm{CAR}=\mathrm{a}+\beta 1 \mathrm{ROA}+\beta 2 \mathrm{BOPO}+\beta 3 \mathrm{NPL}+\beta 4 \mathrm{LDR}+\varepsilon
$$

Based on the table above, the following equation is obtained:

$$
\mathrm{CAR}=0,25+9,677 \mathrm{ROA}+2,468 \mathrm{BOPO} \text { DAU- 0,004 NPL+0,003 LDR }+\varepsilon
$$

Based on the results of calculations on SPSS for windows version 22 in the table above, it can be concluded that ROA has a positive effect on CAR, BOPO has no effect on CAR, NPL has no effect on CAR and LDR has no effect on CAR.

\section{DISCUSSION}

The results of the t-test significance value on the ROA variable on the CAR of 0.023 are smaller than 0.05. This shows that the ROA variable partially has a positive effect on CAR. Thus, the first hypothesis which states that the ROA variable partially affects CAR is supported by data, so that the hypothesis is accepted. The results of this study support the research conducted by Andini, et al (2015) which concluded that ROA has a positive effect on CAR spending. This happened because the condition of commercial banks operating in Indonesia began to improve due to the economic crisis, so that the profits generated by using total assets would reduce the risk level of banks leading to bankruptcy because the total assets held had relatively low risks. 
The result of the significance value of the t-test on the BOPO variable on the CAR of 0.743 is greater than 0.05. This shows that the BOPO variable has no effect on CAR. Thus, the second hypothesis which states that the BOPO variable has no effect on CAR, the second hypothesis is not supported by data, so the hypothesis is rejected.

The results of this study do not support the research conducted by Yuliani, et al (2015) which states that BOPO has an effect on CAR, this happens because the bank is able to maintain the efficiency of operating costs and is smaller than operating income, so this condition will cause profits to be obtained by the bank. the higher it is, in other words the smaller the BOPO reflects a bank's good enough in carrying out its operational activities.

The results of the t-test significance value on the NPL variable on the CAR of 0.608 , greater than 0.05. This shows that the NPL variable has no effect on CAR. Thus, the third hypothesis which states that the NPL variable has no effect on CAR is not supported by data, so the hypothesis is rejected. The results of this study do not support research conducted by Andini, et al (2015) suggesting that NPL has a significant effect on CAR. If a bank has a low NPL, it means that existing non-performing loans are getting lower, the decline in NPL is expected to affect the decline in non-performing loans in a banking company, but with an increase in NPLs this causes an increase in non-performing loans and results in a decrease in profits that should be received from loan interest. . The decline in profit has an impact on capital adequacy, because profit is one of the components that influences the formation of the capital structure of a banking company.

The result of the t-test significance value on the LDR variable on the CAR of 0.225 is greater than 0.05. This shows that the LDR variable has no effect on CAR. Thus, the fourth hypothesis which states that the LDR variable has no effect on CAR is not supported by data, so the hypothesis is rejected. The results of this study do not support the research conducted by Anjani, et al. (2014) suggesting that LDR has a significant effect on CAR. Managers in a company as recipients of the trust of the company owner should determine policies that can increase the importance of the Loan to Deposit Ratio ( LDR) is used to assess the liquidity of a bank by dividing the amount of credit by the amount of funds. Loand to Deposit Ratio (LDR) is a ratio that shows the ability of a bank to provide funds to debtors with capital owned by the bank and funds that can be collected from the people of Dendawijaya (2015). So that the higher this ratio will increase bank capital. Because if managers in the banking sector are unable to increase this ratio, it will reduce the Capital Adequacy Ratio (CAR).

\section{CONCLUSION}

This research was conducted with the aim of examining the effect of Return on Assets (ROA), Operational Costs on Operating Income (BOPO), Non-Performing Loans (NPL) and Loan to Deposit Ratio (LDR) on Capital Adequacy Ratio (CAR). The data of this study were obtained from the published financial reports of each bank listed on the Indonesia Stock Exchange from 2014 to 2018. The sample used was 26 banking companies selected by purposive sampling method.

The variable Return on Assets (ROA) has a positive and positive effect on the Capital Adequacy Ratio (CAR). Because the overall value of Conventional Banks is above the minimum standard value given by Bank Indonesia, which is a minimum of $1.5 \%$. The bank management has worked efficiently in using bank assets so as to generate huge profits or profits. 
Putra, R. N. P., Aysik, N. F., \& Fidiana, (2020). Financial Ratio Determinants of Capital in the Banking Sector Listed on the Indonesia Stock Exchange (IDX). Archives of Business Research, 8(11). 165-173.

Operational Costs on Operational Income (BOPO) partially have no effect on CAR, this is due to an increase in operating costs, this condition will cause the profit earned by the bank to decrease, thus impacting on bad capital ratios and affecting capital adequacy.

Partially Non Performing Loans (NPL) have no effect on CAR, this is due to an increase in nonperforming loans, this condition will cause the profit that should be received from the loan interest to decrease. The decline in profit has an impact on the Capital Adequacy Ratio, because profit is one of the components that influences the formation of the capital structure of a banking company. Loan to Deposit Ratio (LDR) partially has no effect on CAR. because the increase in deposits was smaller than the amount of credit and the overall value of Conventional Banks under the 0JK region, namely $85 \%-110 \%$.

Based on the results of the analysis of the discussion as well as from the conclusions of this study, the suggestions that become research input in order to get better results, namely: if there is further research, not only using samples from conventional banks, it is advisable for further research to use more than one.

\section{Bibliography}

Andini. 2015. Analysis of the Effect of Return on Assets (ROA), Return On Equity (ROE), Non Performing Loans (NPL), and Loan To Deposit Ratio (LDR) on Capital Adequacy Ratio (CAR) in Banking Companies in Indonesia (Case Study on Banks General Indonesian listed on the Indonesia Stock Exchange for the period 2009-2013).

Anjani Ayu Dewa. (2014) Effect of Non Performing Loans (Npl), Liquidity and Profitability on Capital Adequacy Ratio.

Bank Indonesia Regulation Number 10/15 / PBI / 2008 concerning Minimum Capital Requirement for Commercial Banks, State Gazette of the Republic of Indonesia of 2008 Number 135, Supplement to State Gazette of the Republic of Indonesia Number 4895.

Bateni, 2014. The Influential Factors on Capital Adequacy Ratio in Iranian Banks, International Journal of Economics and Finance; Vol. 6, No. 11; 2014 ISSN 1916-971X E-ISSN 1916-9728 Published by Canadian Center of Science and Education 108

Cebenoyan, A. S., \& Strahan, P. E. (2001). Risk Management, Capital Structure, and Lending at Banks. Wharton Financial Institution Center, 1 - 31.

Dendawijaya, Lukman, 2015. Banking Management, Second Edition, Second Edition, Ghalia Indonesia, Bogor Jakarta

Edginarda, Cynthia. 2012. Analysis of the Influence of Profitability and Liquidity Ratios on Capital Adequacy Ratio (CAR) in Government Banks in Indonesia 2003-2010. Thesis-S1. Makassar: Faculty of Economics, Hasanudin University.

Evelina, 2012. The Effect of Profitability Ratios on the Capital Health of National Private Banks on the IDX.

Fatimah, 2013. Effect of Profitability, Efficiency, and Liquidity on Capital Adequacy of Islamic Commercial Banks.

Fitrianto, Hendra and Wisnu Mawardi. 2016. Analysis of the Effect of Asset Quality, Liquidity, Profitability and Efficiency Against Capital Adequacy Ratio of Banks Listed on the Jakarta Stock Exchange. Journal of Management and Organization Studies, Vol 3 no January 1, 2016. Diponegoro University, Semarang

Hariyani Iswi, 2010. Restructuring and Elimination of Bad Credit. Jakarta: PT Elex Media Komputindo.

Hendra Fitrianto, Wisnu Mawardi, Analysis of the Effect of Asset Quality, Liquidity, Profitability, and Efficiency on the Capital Adequacy Ratio of Banks Listed on the Jakarta Stock Exchange, Journal of Management \& Organization Studies Volume 3, Number 1, January, 2006, Page 1 http: / /ejournal.undip.ac.id/index.php/smo

Imam, 2007. Non Performing Loan. Yogyakarta: BPFE Publishing Agency. 
Jensen, M. C and Meckling, W.H. 2016. Theory of the Firm: Managerial Behavior, Agency Costs and Ownership Structure. Journal of Financial Economics, October, 1976, V. 3, No. 4, pp. 305-360. Avalaible from: http://papers.ssrn.com

Manullang, A Laurence, 2002. Analysis of the Influence of Profitability on Capital Adequacy Ratio in National Retirement Savings Bank ", Business Research \& Management Media Vol 2, No. 1, Pages 26- 47

Ministry of Finance (1967), Law on Amendments to Law No. 7 of 1992 concerning Banking. UU no. 10 of 1998, LN No. 182 of 1998, TLN No. 3790.

Nazaf, 2014. The Effect of Asset Quality, Liquidity, and Profitability on Bank Capital Adequacy Level (Empirical Study on Banking Companies Listed on the IDX)

Netty, 2010. The Influence of LDR (Loan To Deposit Ratio), NPL (Non Performing Loan), ROA (Return On Assets) And BOPO (Operating Costs Operating Income) On The Capital Adequacy Of Banks In Banks Listed On The IDX. Thesis Accounting Study Program, Department of Accounting, Faculty of Economics, University of North Sumatra, Medan.

OJK, 2014. Development of the banking world, www.ojk.go.id.

Oktaviana, et al, 2016. The Influence of Size, ROA, FDR, NPF, and BOPO on Capital Adequacy Ratio in Islamic Commercial Banks in Indonesia 2010-2014.

Olalekan, et al 2013. Capital Adequacy And Banks' Profitability: An Empirical Evidence From Nigeria, American International Journal Of Contemporary Research Vol. 3 No. 10; October 2013

Rafet Aktas, Suleyman Acikalin, Bilge Bakin, Gokhan Celik The Determinants of Banks' Capital Adequacy Ratio: Some Evidence from South Eastern European Countries, Journal of Economics and Behavioral Studies Vol. 7, No. 1, pp. 7988, February 2015 (ISSN: 2220-6140)

Shitawati. 2006. "Analysis of the factors that affect the capital adequacy ratio (empirical study: commercial banks in Indonesia 2001 - 2004).

Sudirman, I wayan, 2013. Banking Management Towards Professional Conventional Bankers. Jakarta: Golden.

Sugiyono. 2011. Quantitative Research Methods, Qualitative and R \& D. Bandung: Afabeta

Wahidahwati. 2012. "The Effect of Managerial Ownership and Institutional Ownership on Company Debt Policy: A Theory Agency Perspective", Indonesian Accounting Research Journal, Vol. 5, No.1, January: Pages 1-16.

Wulandari, The Effect of Liquidity and Profitability on the Capital Adequacy Ratio in the Open Banking Sector in Indonesia, University of North Sumatra, Faculty of Economics

Yuliyani, et al. (2015. Effect of Loan To Deposit Ratio, Non Performing Loans, Return On Assets and Operational Costs on Operational Income (BOPO) on Capital Adequacy Ratio (Study on National Private Commercial Bank (BUSN)

Foreign Exchange). 